\title{
The Implementation of Technology in Adult Learning in Community Education Units
}

\author{
Jajat S Ardiwinata*, Uyu Wahyudin, Dadang Yunus, Purnomo, Hodijah Wulandari \\ Community Education Department \\ Universitas Pendidikan Indonesia \\ Bandung, Indonesia \\ *jsardipls@upi.edu,dinpls@upi.edu,dadangyunus@upi.edu,purnomo@upi.edu,hodijahw@student.upi.edu
}

\begin{abstract}
The digital era makes it easy for everyone to access information in everyday life. The sophistication of digital technology accompanied by digital devices has made major changes to human life. Various groups have facilitated access to information in many ways, and can enjoy the facilities of digital technology freely and under control. However, currently the implementation of technology in learning has not been evenly applied effectively, especially for technology users as adults in community education units. It is necessary to do research, to find out to what extent learners are able to use and utilize technology for learning purposes. This research was conducted for 6 months by applying quantitative descriptive research methods survey techniques. The survey was distributed to learning citizens in 4 community education units totaling 72 people with an age range of 25-40 years. The results show that learning citizens already have digital literacy and are able to implement technology in adult learning characterized by ownership of technology devices and their use for e-learning needs and other daily life needs as well as mastery of multimedia skill, graphic design, and use of Microsoft Office to support learning.
\end{abstract}

Keywords-digital literacy, technology, adult learning

\section{INTRODUCTION}

Adult learners refer to the condition of adult learners in terms of biological, psychological, and social dimensions which can be divided into three categories, namely early adults from 16 to 20 years of age, middle adults from 20 to 40 years, and late adulthood. 40 to 60 years [1]. Meanwhile, in the Adult Education Survey in the European Union, the adult population is those aged 25-64 years [2]. Meanwhile in the United States, adult learners refer to non-traditional adult learners (NALs). NALs are people aged 25 years and over, including those under 25 but have characteristics that indicate adult responsibilities, such as working full time, not being able to go to college or not completing high school [3,4]. Meanwhile in Indonesia, adult learners tend to emphasize biological characteristics rather than psychological and social characteristics.

Given that adults are interpreted differently by different cultures, adults in the context of ALE (Adult Learning and Education) represent all people involved in ALE, even including those who have not yet reached chronological age (in contexts such as NALs), middle-aged, and old age, it is important that they are involved as learners in various forms of ALE [5]. Thus, adults in the context of ALE are not limited by age, social role, and other demographic characteristics, but rather include all populations that have the opportunity of access to and are involved in ALE. This broadening of the ALE perspective regarding adult boundaries is wise enough to allow everyone to participate in ALE [6,7].

Understanding the logic of generations and the knowledge of different generations can help make the learning process more effective and efficient. The generation stage based on the year of birth is currently known as four generations, namely: (1) Boomer: born 1946-1964, aged 54-72 years, (2) Gen $X$ : born 1965-1980, age 38-53 years, (3) Millennials / Gen $Y$ : born 1980-1995, ages 23-37 years), and (4) Gen Z / Digital Natives: born 1995-2010, ages 8-22 years [8-11]. Given that the Digital Native generation are those born in 1995 who are currently aged 0-22 years, most adult learners in the digital era are Digital Immigrants who are currently 23-72 years old.

Digital Immigrant as a subject of adult learning has opposite characteristics from the Digital Native. Digital Immigrant can only do one job at a time, prefers to read in hardcopy format, thinks that those who have a lot of knowledge are those who have a lot of writing, work consistently and gradually so that it takes more time, and are just starting to learn technology. On the other hand, Digital Native is able to do multiple tasks at one time, prefers reading from the screen, prefers multimedia over text, better understands multimedia concepts, technology users, and sees no difference between the offline and online worlds. The uniqueness of the characteristics of adults as Digital Immigrants needs to be the main concern of educators and education managers in designing diversified ALE programs and services now and in the future.

To achieve a challenge at the top, top notch technology in adult education programs and technology is to facilitate the purpose and goals of the community itself [8,12-14]. Technology as a strategic approach to achieve community needs with a broad, limited reach by space and time, as well as 
limited interaction or communication. Behind the benefits of this technology, the problems of community life are inherent in community empowerment programs that can be supported by solving problems through technology. Community empowerment programs are closely related to a paradigm shift in a person or society, which will occur if it goes through the educational process. The actor of community empowerment as an educational process is the gap or gap in the problems of human life needs, environmental problems that do not support the life of the community, even the opposite is true for people's lives that are not conducive to their environment [15-17].

As explained by AONTAS [18] that community education is education and learning that is rooted in the process of empowerment, social justice, change, challenges, respect and collective awareness. These process exist in the community and society as a perpetrator, which reflect the individual needs and the needs of local communities that are developing. The process of building community capacity is carried out in the form of involvement in decision making and policy formation in the community [18].

Community empowerment programs as an educational process have a heterogeneous approach to services, programs and resources. From a sociological perspective, public education is a complex education, because it is related to technique, location and does not only talk about content. The Green Paper (1998) in Connolly [19] and The White Paper on adult education, considers public education as an ideology, which is " a communal education process towards empowerment, both at the individual and collective level. This is an interactive and challenging process, not only in terms of content, but also in terms of methodology and decision making" DES (2000: 110) in Connolly [19].

The focus of this research study is to explore research information about the utilization of digitalization for adults.

\section{METHODS}

This research approach uses survey techniques and descriptive quantitative analysis. Descriptive survey techniques are used to measure carefully certain phenomena without testing hypotheses. As the opinion [20], surveys can be carried out with the sole purpose of providing an overview of something. To get data from a topic in a flexible manner from events in certain conditions with a cross-sectional survey type [21]. The population of this study amounted to 103 people, while the sample used was $70 \%$ or 72 people.

The involvement of respondents or informants in this study will affect the results of the study. All participants in this study were 72 respondents who studied citizens in 4 community education units. The characteristics of respondents and informants in this study are active status as learning citizens with an age range of 25-40 years which is the middle adult age category [1]

\section{FINDINGS AND DISCUSSION}

The implementation of technology in adult learning can be seen through digital literacy skills, digital literacy skills are not only be able to read, write by utilizing digitization, but also how the basic skills and attitudes or perspectives of users towards technology [22-26]. Digital literacy involves more than just the ability to use software or operate digital devices; it includes a wide variety of complex cognitive, motor, sociological, and emotional skills that users need to function effectively in a digital environment [27]. The effect of digitalization on life is very large, down to the realm of the ability to improve the economy or entrepreneurship.

Adult digital literacy, especially citizens learning of community education, has an age range of 25-40 years which is the middle adult age category [1] found that knowledge skills and attitudes are in line with the development of technology implementation in the current learning process. To find out the general description of respondents regarding digital literacy in the implementation of adult learning that has been disseminated, are as follows:

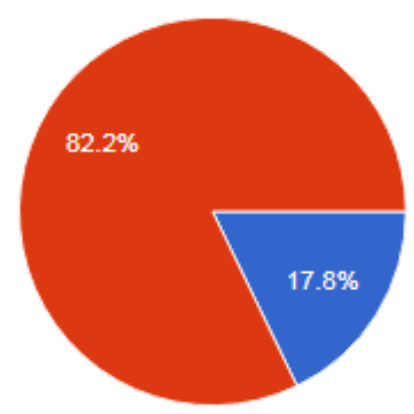

Fig. 1. Respondent gender.

Based on the results of a survey conducted on 72 respondents, it is known that $82.2 \%$ (60 people) of respondents were female and the remaining $17.8 \%$ (13 people) were male. The majority of study residents who took the survey were female.

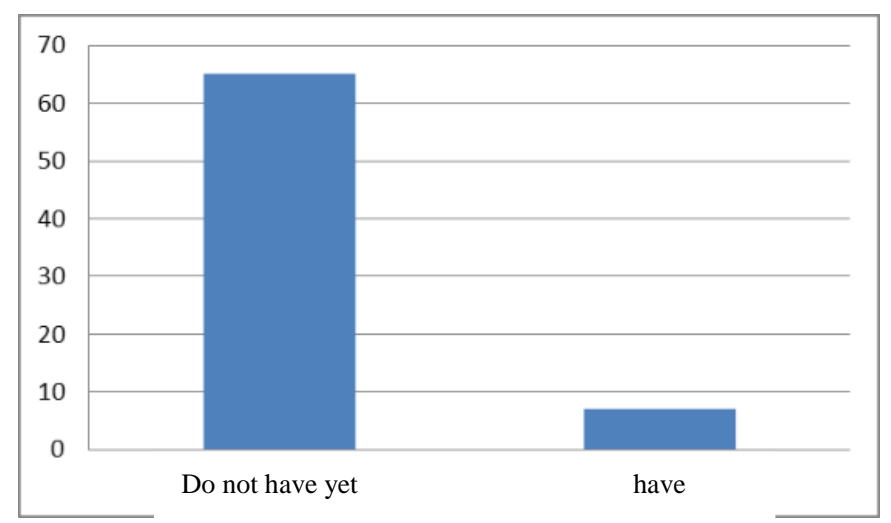

Fig. 2. Ownership of desktop computer equipment. 


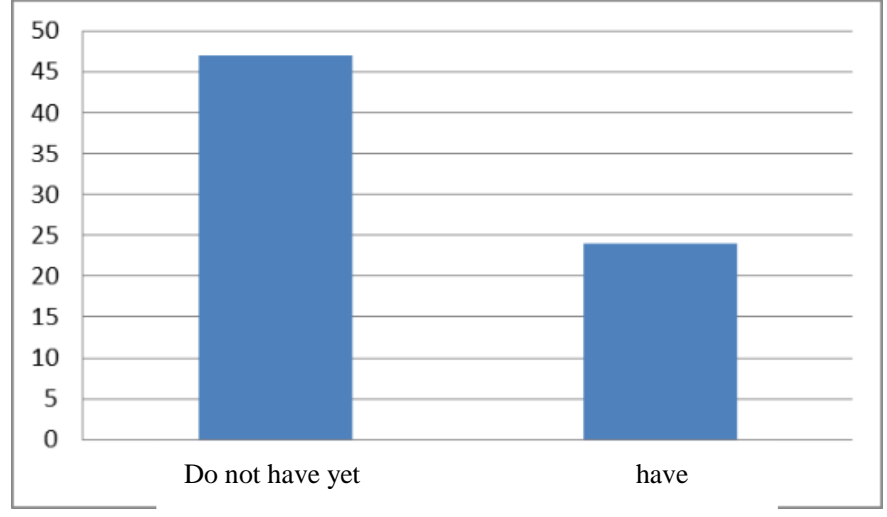

Fig. 3. Ownership of laptop computer equipment.

Based on figure 2, the survey results show that out of 72 respondents, $66.2 \%$ (48 people) do not have a desktop computer and $33.8 \%$ (24 people) have a desktop computer, while in Figure 3, the survey results shows 92.9\% (65 people) do not have laptops and $7.1 \%$ (5 people) have laptops to support their learning. This shows that to support adult learning, the majority of adults do not have a laptop computer as a technological device, but take advantage of the availability of infrastructure in their respective community education units.
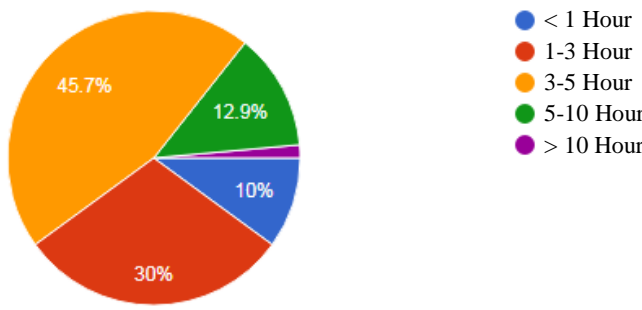

Fig. 4. Frequency of computer usage in a day.

Based on the results of a survey conducted on 72 respondents, it was found that $1.4 \%$ ( 1 person) used to use a computer for more than 10 hours a day, $10 \%$ (7 people) used a computer for less than 1 hour every day, $12.9 \%$ ( 9 people) use a computer for $5-10$ hours every one day, $30 \%$ (21 people) use a computer for 1-3 hours every one day and the remaining $45.7 \%$ (32 people) use a computer for $3-5$ hours every day. The use of computers is based on time, showing the intensity of citizens learning as adults using computers, this shows that the majority of adults often face computers every day.
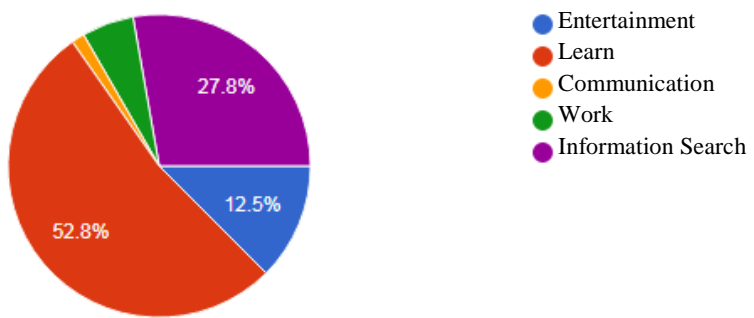

Fig. 5. Purpose of using a computer connected to the internet.
Based on the survey results above, it is known that $1.4 \%$ (1 person) use a computer connected to the internet to communicate, as many as $5.6 \%$ (4 people) use a computer connected to the internet for work, as many as $12.5 \%$ (9 people) use a computer connected to the internet to find entertainment, $27.8 \%$ (20 people) use a computer connected to the internet to search for information, and the remaining $52.8 \%$ (38 people) use a computer connected to the internet to learn. This shows that the majority of citizens learning as adults use computers as a technological device that supports their learning process.
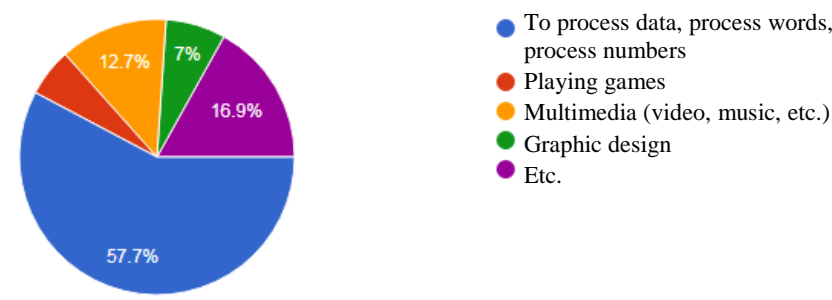

Fig. 6. Purpose of using a computer without internet connection.

Based on the survey results above, if the respondent uses a computer without being connected to the internet, as many as $5.6 \%$ (4 people) use computers to play games, as many as $7 \%$ (5 people) use computers to do graphic design, as many as $12.7 \%$ (9 people) using computers for multimedia use (videos, music and others), as many as $16.9 \%$ (12 people) used computers for other reasons and the remaining 57.7\% (41 people) used computers to process data, process words, and crunching numbers. This shows that the use of computers without being connected to the internet can support the learning process by utilizing data processing technology, word processing and number processing that are on the computer itself.

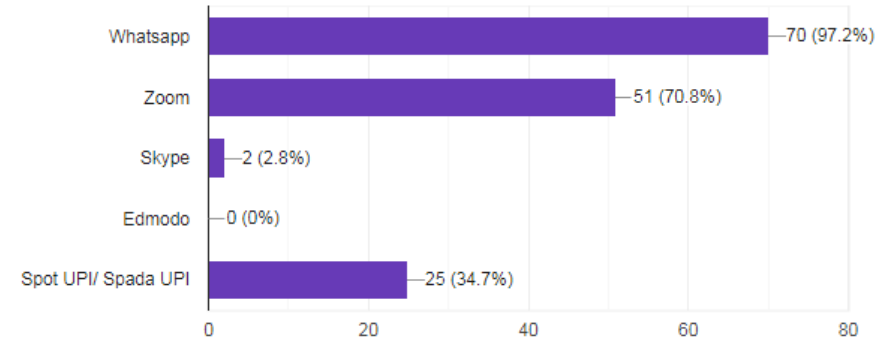

Fig. 7. Online applications that are often used in learning.

Based on the results of a survey of 72 respondents, $97.2 \%$ (70 people) chose the WhatsApp application as an online application that is often used in learning. As many as $70.8 \%$ (50 people) chose the zoom application as anline application that is often used in learning. As many as $34.7 \%$ (25 people) chose the UPI/Spada UPI spot application as an online application that is often used in learning and the remaining $2.6 \%$ (2 people) chose the Skype application as an online application that is often used in learning. 


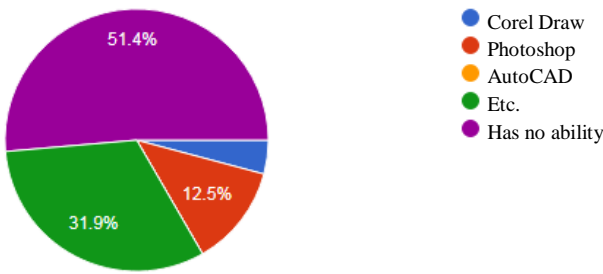

Fig. 8. Owned graphic design capabilities.

Based on the survey results above, the graphic design skills mastered by 72 respondents, as many as $4.2 \%$ ( 3 people) have the ability to design graphics using the Corel Draw application, as many as $12.5 \%$ (9 people) have the ability to design graphics using the Photoshop application, As many as 31.9\% (23 people) have graphic design skills using other applications and the remaining $51.4 \%$ (37 people) do not have graphic design skills. This shows that more learning citizens have graphic design skills by utilizing technology.
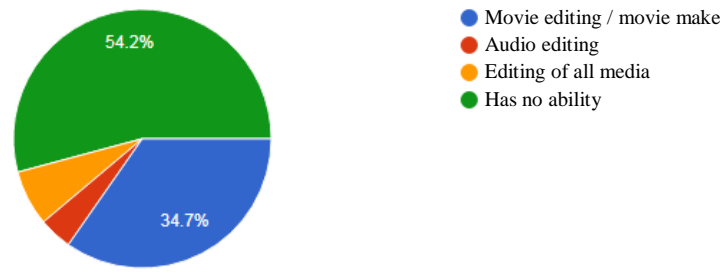

Fig. 9. Mastered multimedia capabilities.

Based on the survey results above, as many as $4.2 \%$ (3 people) have multimedia skills that are mastered in the form of audio editing. As many as $34.7 \%$ ( 25 people) have multimedia skills that are mastered in the form of editing movie / movie maker. A total of $6.9 \%$ (5 people) have multimedia skills that are mastered in the form of editing all multimedia and as many as $54.2 \%$ (39 people) do not have multimedia capabilities. This shows that in multimedia mastery, there are more people learning as adults who do not have multimedia abilities that they master than those who already have these abilities.

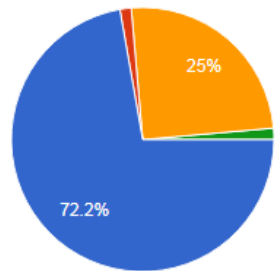

Microsoft Word

- Microsoft Excel

Power Point

Has no ability

Fig. 10. The most mastered basic Microsoft Office skills

Based on the results of the survey above, the basic skills of Microsoft Office which were most controlled by 72 respondents were the ability to operate Microsoft Word as many as $72.2 \%$ ( 52 people), as many as $25 \%$ (18 people) had the most proficiency in operating Microsoft Power Point, as many as $1.4 \%$ (1 person) has the most proficiency in operating Microsoft Excel and 1.4\% (1 person) does not have the most basic Microsoft Office skills.

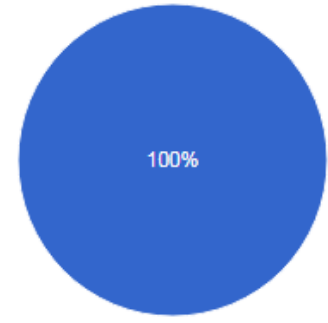

Yes

Fig. 11. Smartphone ownership.

Based on the survey results above, it shows that as many as $100 \%$ (72 people) own a smartphone. This means that in today's technology, adults all own smartphones.

Based on the explanation above, it can be explained in general that literacy has been a part of human life since ancient times. In the past, humans only read signs of nature, through certain symbols that humans in their day understood. Now as time goes by, reading is in the form of writing which is a series of words and numbers from the thinking of humans. Writing is now the result of data processing that becomes information for fellow humans. In the industrial era 4.0, literacy is not immune from the influence of technological developments.

Technological developments are not only in terms of hardware such as computers, but also rapid advances have occurred in software. Text-based applications exist in every digital media which ultimately makes it easier for humans. The generation that grew up in this modern era is certainly required to be responsible for the way they use technology. This unlimited access changes the interaction patterns of the generations that grew up in the past. So, the use of this technology is ultimately determined by each individual. The increase in a strong internet network also supports humans to be able to surf and find information more easily. Therefore, digital literacy is now no stranger to society.

Every individual needs digital literacy to be able to participate in today's modern world. Digital literacy will create a society with a creative and critical mindset. The results show that digital media such as computers, internet and smartphones are familiar in society [28,29]. Citizens learning as adults perceive that the three media can support education, work and other activities.

In fact, most of them have used digital media every day, both for education with the use of e-learning applications to information retrieval, for work by processing words, data and numbers, for entertainment by playing multimedia, and for communicating with other people through the media social.

Therefore, digital literacy is a competency that not only involves the ability to use technology, information and communication tools, but also the ability to socialize, the ability to think critically, creatively, and inspire as digital competences.

The self-taught citizens who were none other than the respondents of this study revealed that they mostly used 
computers in one day with a frequency of 3-5 hours. This shows that the use of technology is very high.

Maulana [30] revealed that everyone must have digital literacy skills so that they can easily search, find, evaluate, create, utilize and re-disseminate this information. Humans are said to be digital literates if they are able to "...use these skills and the appropriate technology to communicate and collaborate with peers, colleagues, family, and on occasion, the general public..." [31] and collaboration is the key word in digital literacy.

Additional information show that $66.2 \%$ of the learners have a desktop computer and $92.9 \%$ learners have a computer device laptop and $100 \%$ learners have a smartphone. This shows that on average they have at least one technology device to support educational activities, work, or others. The position of digital literacy is very important for learning citizens because it will make their work easier. The use of information technology in education opens opportunities for learning citizens to access information, as well as in processing and finding out about broader knowledge. The use of technology in collecting learning data and information, in addition, it can be used to save time and money.

Digital literacy can make people make better decisions because it allows to search for information, study, analyze and compare them anytime. If the individual is able to make decisions to act, then in fact he has obtained valuable information [32] said that in general, information is considered valuable if it influences the recipient to make a decision to act.

\section{CONCLUSION}

The implementation of technology in adult learning needs to be supported by digital literacy skills possessed by these adults. The results of this study indicate that in adult learning among learning citizens already have digital literacy and have started implementing technology in adult learning, it is marked by the ownership of technological devices and their use for elearning purposes and the needs of daily life. In addition, they also have mastery of multimedia capabilities, graphic design, and use of their Microsoft Office to support this learning.

\section{ACKNOWLEDGMENT}

Thanks to the Institute for Research and Community Service (Lembaga Penelitian dan Pengabdian kepada Masyarakat, LPPM), Universitas Pendidikan Indonesia for funding this research.

\section{REFERENCES}

[1] C. Colarusso and R. Nemiroff, Adult Development: A new dimension in psychodynamic theory and practice. New York: Springer Science+Business Media, LLC. 1981.

[2] Adult Participation in Learning. Eurostat, 1. 2018.

[3] J. Chen, "Nontraditional Adult Learners: The Neglected Diversity in Postsecondary Education". SAGE Open, 7(1), pp. 1-12. 2017.
[4] J. McFarland, B. Hussar, X. Wang, J. Zhang, K. Wang, A. Rathbun, ... F.B. Mann, "The Condition of Education 2018". NCES 2018-144. National Center for Education Statistics. 2018.

[5] UIL. Third Global Report on Adult Learning and Education. 2016.

[6] J. Lee, "Conceptual foundations for understanding inequality in participation in adult learning and education (ALE) for international comparisons". International Journal of Lifelong Education, 37(3), 297 314. 2018.

[7] J. Lee and R. Desjardins, "Changes to adult learning and education (ALE) policy environment in Finland, Korea and the United States: implications for addressing inequality in ALE participation". Compare: A Journal of Comparative and International Education, 1-19. 2019.

[8] S. Brock, Closing the generation gap: understanding Millennials. Rutgers University-Camden Graduate School. 2018.

[9] Nagy and Kolscey. Generation Alpha: Marketing or Science? De Gruyter Open, 7(I). 2017.

[10] R.A. Suggs, Career Development Professionals' Perceived Self-Efficacy with Baby Boomers from the Automotive Industry. 2020.

[11] E. Venter, "Bridging the communication gap between Generation Y and the Baby Boomer generation". International Journal of Adolescence and Youth, 22(4), 497-507. 2017.

[12] Y. Chen, H. Lou, and W. Luo, "Distance Learning Technology Adoption: A Motivation Perspective". Journal of Computer Information Systems, 42(2), 38-43. 2002.

[13] P. Maharg, "Editorial: Learning/Technology". The Law Teacher, 50(1) 15-23. 2016

[14] P. Purnomo, A. Hufad, U. Wahyudin, A.S. Akhyadi, and D.Y. Lutfiansyah, "Needs Assessment Knowledge from Facilitator of Community Empowerment Program in the Digital Era". Journal of Nonformal Education, 6(2), 130-138. 2020.

[15] J. Alajääski and J. Suomala, "Another perspective on assessing the significance of information technology in education". Computers in the Schools, 18(2-3), 111-125. 2001.

[16] R. Diem, Computers in Education (1988): A Research Bibliography. Routledge. 2018.

[17] G.E. Snelbecker, "Impact of computers and electronic technology on the teaching methodologies and the learning process". Journal of Children in Contemporary Society, 14(1), 43-53. 1982.

[18] AONTAS. Community Education: AONTAS Policy Series. Dublin. 2000

[19] B. Connolly, Community Education: Listening to the Voices in The Adult Learner: Community Education. AONTAS \& AEOA, Dublin 2003.

[20] Soehartono. Metode Penelitian Sosial. Bandung: PT Remaja Rosdakarya. 2000

[21] J. Navarro-Rivera and B.A. Kosmin, "Surveys and questionnaires". The Routledge Handbook of Research Methods in the Study of Religion, 395-420. 2013

[22] J. Avila and M. Moore, "Critical literacy, digital literacies, and common core state standards: A workable union? Theory Into Practice", 51(1), 27-33. 2012.

[23] J.P. Drake, Civil talks: Analysis of online discussions in social studies classrooms. Kent State University. 2012

[24] P.T. Jaeger, J.C. Bertot, K.M. Thompson, S.M. Katz, and E.J. DeCoster, "The intersection of public policy and public access: Digital divides, digital literacy, digital inclusion, and public libraries". Public Library Quarterly, 31(1), 1-20. 2012.

[25] H. Julien, "Digital literacy". In Encyclopedia of Information Science and Technology, Third Edition (pp. 2141-2148). IGI Global. 2015.

[26] A.H. Purnomo, U. Wahyudin, A.S. Akhyadi, N. Sutarni, and A. Rahmat, "Model Digital Needs Assessment Program of Community Empowerment". International Journal of Control and Automation, 13(4), 401-411. 2020 
[27] Y. Eshet-alkalai, "Digital Literacy: A Conceptual Framework for Survival Skills in the Digital Era". 13, 93-106. 2004.

[28] Hufad, P. Achmad, "Digital literacy of women as the cadres of community empowerment in rural areas". International Journal of Innovation, Creativity and Change, 9(7), 276-288. 2019. Retrieved from https://www.scopus.com/inward/record.uri?partnerID=HzOxMe3b\&scp $=85078889846 \&$ origin $=$ inward
[29] A. Hufad, U. Wahyudin, A.S. Akhyadi, and N.P. Sutarni, "Model Digital Needs Assessment Program of Community Empowerment". 13(4), 401411. 2020.

[30] Maulana. Definisi, Manfaat Dan Elemen Penting Literasi Digital. 2019.

[31] ALA Digital Literacy Taskforce. What Is Digital Literacy?. 2011.

[32] I.F. Priyanto, Era Zettabyte dan Matinya Etika. 2013. 